\title{
Prediction of drinking water intake by dairy cows
}

\author{
J. A. D. R. N. Appuhamy, ${ }^{* 1}$ J. V. Judy, † E. Kebreab, ${ }^{*}$ and P. J. Kononoff† \\ *Department of Animal Science, University of California, Davis 95616 \\ †Department of Animal Science, University of Nebraska, Lincoln 68583
}

\section{ABSTRACT}

Mathematical models that predict water intake by drinking, also known as free water intake (FWI), are useful in understanding water supply needed by animals on dairy farms. The majority of extant mathematical models for predicting FWI of dairy cows have been developed with data sets representing similar experimental conditions, not evaluated with modern cows, and often require dry matter intake (DMI) data, which may not be routinely available. The objectives of the study were to (1) develop a set of new empirical models for predicting FWI of lactating and dry cows with and without DMI using literature data, and (2) evaluate the new and the extant models using an independent set of FWI measurements made on modern cows. Random effect meta-regression analyses were conducted using 72 and 188 FWI treatment means with and without dietary electrolyte and daily mean ambient temperature (TMP) records, respectively, for lactating cows, and 19 FWI treatment means for dry cows. Milk yield, DMI, body weight, days in milk, dietary macro-nutrient contents, an aggregate milliequivalent concentration of dietary sodium and potassium $(\mathrm{NaK})$, and TMP were used as potential covariates to the models. A model having positive relationships of DMI, dietary dry matter (DM\%), and $\mathrm{CP}(\mathrm{CP} \%)$ contents, NaK, and TMP explained $76 \%$ of variability in FWI treatment means of lactating cows. When challenged on an independent data set (n $=261$ ), the model more accurately predicted FWI [root mean square prediction error as a percentage of average observed value $(\mathrm{RMSPE} \%)=14.4 \%]$ compared with a model developed without NaK and TMP (RMSPE\% $=17.3 \%)$, and all extant models (RMSPE $\% \geq 15.7 \%$ ). A model without DMI included positive relationships of milk yield, DM\%, NaK, TMP, and days in milk, and explained $63 \%$ of variability in the FWI treatment means and performed well (RMSPE\% $=17.9 \%$ ), when challenged on the independent data. New models for

Received January 26, 2016.

Accepted May 3, 2016.

${ }^{1}$ Corresponding author: jaappuhamy@ucdavis.edu dry cows included positive relationships of $\mathrm{DM} \%$ and TMP along with DMI or body weight. The new models with and without DMI explained 75 and $54 \%$ of the variability in FWI treatment means of dry cows and had RMSPE\% of 12.8 and $15.2 \%$, respectively, when evaluated with the literature data. The study offers a set of empirical models that can assist in determining drinking water needs of dairy farms.

Key words: dairy cow, empirical model, water intake, sodium, potassium

\section{INTRODUCTION}

The World Economic Forum lists water crisis among the top 10 likely global risks. Currently, agriculture accounts for approximately $70 \%$ of the world's total water consumption and this use is likely to increase to meet the growing demand for food (Schulte et al., 2014). It has been estimated that dairy cattle account for approximately $19 \%$ of the total global water footprint related to animal production, and of the total amount of water used to produce all animal food products, $98 \%$ is used to produce feed, whereas $1 \%$ is used for drinking (Hoekstra, 2012). Despite accounting for only a small proportion of the total amount of water needed to produce milk, water acquired through drinking is vital for production. This is illustrated by the fact that restriction of water has been shown to result in rapid, but usually reversible, reductions in feed intake and milk yield (Steiger Burgos et al., 2001). Lactating dairy cows have the highest free water intake (FWI) and also experience the largest flux of water of any domesticated ruminant (Woodford et al., 1984). Interestingly, the nutritional requirements for water vary by as much as a factor of 10 (Lassiter and Edwards, 1982), whereas the daily body water flux of a lactating dairy cow may be as high as 30\% of its total body water (Beede, 2012).

Accurately quantifying FWI may be needed for a variety of purposes including understanding water intake requirements of animals in dairy farms. Estimates of FWI may also be useful when attempting to match available resources to newly constructed facilities. To do so, several mathematical models have been published 
and may be used to predict FWI in dairy cattle (e.g., Castle and Thomas, 1975; Little and Shaw, 1978; Murphy et al., 1983; Stockdale and King, 1983; Holter and Urban, 1992; Dahlborn et al., 1998; Meyer et al., 2004; Cardot et al., 2008; Khelil-Arfa et al., 2012; Appuhamy et al., 2014b). The majority of extant models require DMI of individual cows as an input, which may not be routinely available in commercial dairy farms. A few extant models (Castle and Thomas, 1975; Dahlborn et al., 1998; Khelil-Arfa et al., 2012) allow for predicting FWI without using DMI. Nonetheless, the performance of some of these equations has not been evaluated using independent FWI measurements, particularly from modern cows under current management. Additionally, the majority of the extant equations have been developed using data from feeding studies sharing similar experimental contexts and facilities. Therefore, successful extrapolation of these models to diverse commercial dairy herds might be limited. On the other hand, meta-analytic approaches can be applied to derive new equations presumably with greater extrapolation capacity using literature data covering different experimental contexts, diets, and animal characteristics. Particularly, the random-effect meta-analytic approaches support extrapolation as they assume data used for model development to be a random sample of the total population (Viechtbauer, 2010). The objectives of the present study were to (1) explore factors significantly associated with FWI and develop a set of empirical models for predicting FWI of lactating and dry cows using random-effect meta-analyses of literature data, and (2) evaluate extrapolation capacity of the new and extant models using an independent data set including FWI measurements made on modern cows.

\section{MATERIALS AND METHODS}

\section{Data Sources}

An extensive literature search was conducted for in vivo studies reporting measured FWI of lactating and dry dairy cows along with related information on DMI, dietary nutrient composition, milk yield, DIM, and BW. For lactating cows, 239 treatment means of FWI were retrieved originally from 69 research articles (Table 1). After excluding treatment means without corresponding measures of uncertainty (e.g., SD or SEM), sample size $(\mathrm{N})$, treatment means of restricted water intake, and treatment means related to water treatments having significant effects on FWI, the final data set for lactating dairy cows included 188 FWI records published in 55 articles. Forty-three out of the 55 articles, or $78 \%$ of the studies, provided multiple FWI treatment means. Ninety-three percent of the FWI records were related to Holstein cows (81\%) and their crosses (12\%). Experiments conducted with dairy cows in North America (47\%), Europe (25\%), and Australia (8\%) provided the majority of the records. Ten percent of the records were related to pasture-based diets, whereas the rest were from cows offered rations in the form of a TMR. Corn silage (13.0 to $74.5 \%$ of DM), grass or legume hay (4.0 to $81 \%$ of DM), alfalfa silage ( 7.7 to $83.8 \%$ of DM), and grass silage (17.4 to $63.5 \%$ of DM) were the major forage sources, whereas ground corn (2.6 to $46.3 \%$ of DM), barley grain ( 7.2 to $30.8 \%$ of DM), and soybean meal (1.0 to $24.0 \%$ of DM) were the major concentrate ingredients in TMR diets. Only 72 FWI measurements from 16 studies had information on both dietary $\mathrm{Na}$ and $\mathrm{K}$, and ambient temperature (TMP). Dietary Na content (\% of DM) in studies using salt blocks (e.g., Andersson et al., 1984; Bahman et al., 1993) included $\mathrm{Na}$ intake from salt blocks expressed relative to the DMI. A summary of the complete and subset data with dietary $\mathrm{Na}$ and $\mathrm{K}$, and TMP records is given in Table 1. For dry cows, 19 treatment means of FWI and the other information were retrieved from 10 studies. A summary of dry cow data is given in Table 2 .

\section{Model Development and Evaluation}

Lactating Cows. Three-level (cow $\rightarrow$ treatment group $\rightarrow$ study) random-effect model analyses were conducted first to quantify variability or heterogeneity of FWI across treatment groups within individual studies $\left(\boldsymbol{\tau}_{\mathrm{T}^{2}}{ }^{2}\right)$ and among studies $\left(\boldsymbol{\tau}_{\mathrm{S}}{ }^{2}\right)$. Summation of $\tau_{\mathrm{T}}{ }^{2}$ and $\tau_{\mathrm{S}}{ }^{2}$ gave the total heterogeneity of FWI measurements $\left(\boldsymbol{\tau}^{2}\right)$. The 3-level random-effect model (Konstantopoulos, 2011) is given by

$$
Y_{i j}=\mu+\eta(S)_{j}+\nu(T)_{i j}+\varepsilon_{i j}
$$

where $Y_{i j}=$ mean FWI of the $i$ th treatment group in the $j$ th study, $\mu=$ overall mean, $\eta(S)_{j}=j$ th studyspecific random deviation of FWI, which is assumed to be normally distributed with a mean 0 and variance of $\tau_{\mathrm{S}}{ }^{2}, \nu(T)_{i j}=$ random deviation of FWI specific to the $i$ th treatment in the jth study, which is assumed to be normally distributed with a mean 0 and variance of $\tau_{\mathrm{T}}{ }^{2}$, and $\varepsilon_{i j}=$ sampling error or random variability of FWI among cows in the $i$ th treatment of the $j$ th study. Variance of $\varepsilon_{i j}$ is assumed to be known and calculated using standard deviation of the treatment means. When standard deviation was not reported, it was estimated with other uncertainty measures reported (e.g., SEM) and $\mathrm{N}$ as described in Alvarez-Fuentes et al. (2016).

The random-effect models were extended to mixedeffect models or meta-regression models including fixed 
Table 1. A summary of full data set including 188 treatment means of FWI of lactating dairy cows from 55 studies and a subset with only 72 FWI treatment means from 16 studies having dietary sodium and potassium, and ambient temperature records

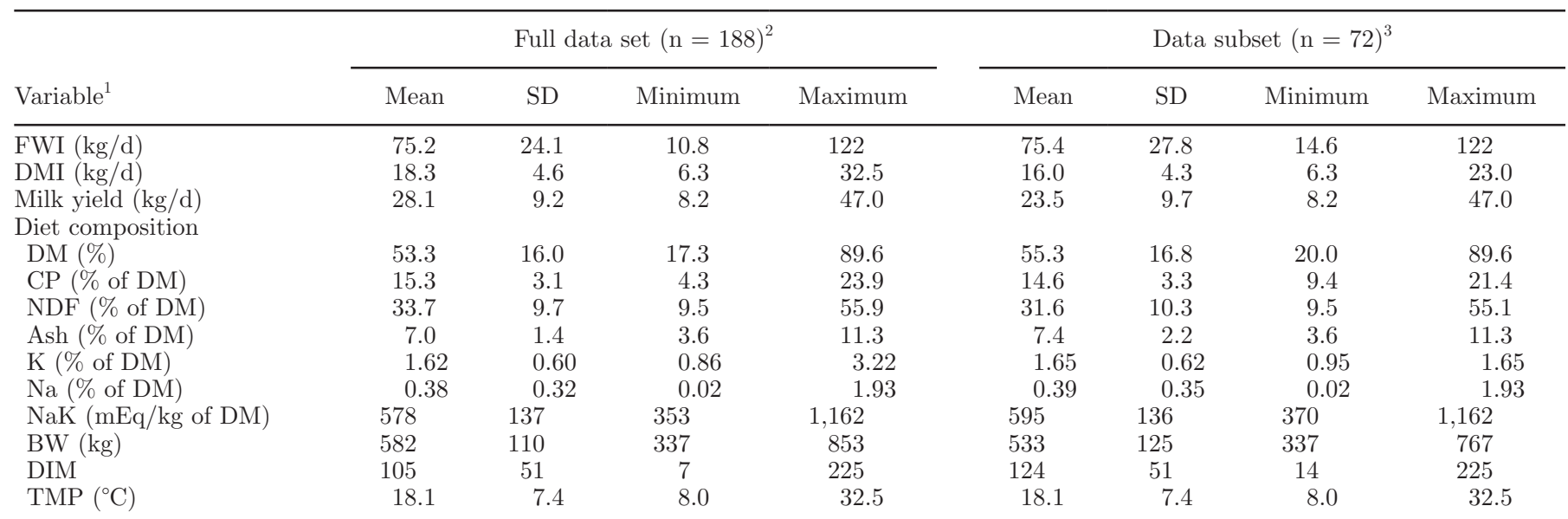

${ }^{1} \mathrm{FWI}=$ drinking water intake, $\mathrm{DM}=$ dietary dry matter, $\mathrm{CP}$ and $\mathrm{NDF}=$ dietary $\mathrm{CP}$ and NDF contents, respectively; ash = total ash content; $\mathrm{NaK}=$ aggregated $\mathrm{Na}$ and $\mathrm{K}$; and $\mathrm{TMP}=$ daily mean ambient temperature.

${ }^{2}$ Castle and Watson, 1973; Castle and Thomas, 1975; Little et al., 1976; Holter et al., 1982; Murphy et al., 1983; Stockdale and King, 1983; Andersson et al., 1984; Woodford et al., 1984; Andersson, 1985; Janicki et al., 1985; Nocek and Braund, 1985; Richards, 1985; Anderson, 1987; Gorewit et al., 1989; Holter et al., 1990, 1992; Shalit et al., 1991; Holter and Urban, 1992; Bahman et al., 1993; Dado and Allen, 1993, 1994, 1995, 1996; Silanikove et al., 1997; Dahlborn et al., 1998; Dewhurst et al., 1998; Muller et al., 1994; Mooney and Allen, 1997; Burgos et al., 2001; Osborne et al., 2002a, 2009; Voelker and Allen, 2003; Cottee et al., 2004; Meyer et al., 2004; Taylor and Allen, 2005; Harvatine and Allen, 2006; Chaiyabutr et al., 2007, 2008; Thomas et al., 2007; Cardot et al., 2008; Kume et al., 2008, 2010; Longuski et al., 2009; Kramer et al., 2009; Shapasand et al., 2010; Khelil-Arfa et al., 2012, 2014; Spek et al., 2012; Stocks and Allen, 2012; Brown and Allen, 2013; Genther and Beede, 2013; McBeth et al., 2013; Appuhamy et al., 2014b; Eriksson and Rustas, 2014; Reith et al., 2014.

${ }^{3}$ Holter et al., 1982, 1990; Stockdale and King, 1983; Andersson et al., 1984; Shalit et al., 1991; Bahman et al., 1993; Silanikove et al., 1997; Osborne et al., 2002b; Cottee et al., 2004; Meyer et al., 2004; Chaiyabutr et al., 2007, 2008; Spek et al., 2012; Genther and Beede, 2013; Eriksson and Rustas, 2014; Khelil-Arfa et al., 2014.

effects of explanatory variables. The mixed effect models are given by

$$
Y_{i j}=\beta_{0}+\beta_{1} X_{i j 1}+\ldots+\beta_{\mathrm{p}} X_{i j \mathrm{p}}+\eta(S)_{j}+\nu(T)_{i j}+\varepsilon_{i j},
$$

where $X_{i j 1}$ and $X_{i j \mathrm{p}}=$ value of the first and the last explanatory variables related to FWI in the $i$ th treatment group of the $j$ th study, respectively; $\beta_{0}=$ intercept; $\beta_{1}$ and $\beta_{\mathrm{p}}=$ regression coefficients of first and

Table 2. A summary of dry cow data ${ }^{1}$

\begin{tabular}{lccc}
\hline Variable $^{2}$ & Mean & Minimum & Maximum \\
\hline FWI (kg/d) & 35.0 & 16.0 & 66.5 \\
DMI (kg/d) & 11.4 & 6.7 & 21.8 \\
Diet composition & & & \\
DM (\%) & 47.8 & 37.9 & 83.2 \\
CP (\% of DM) & 14.7 & 9.9 & 16.6 \\
NDF (\% of DM) & 42.4 & 34.1 & 65.8 \\
BW (kg) & 700 & 605 & 786 \\
TMP ( $\left.{ }^{\circ} \mathrm{C}\right)$ & 16.4 & 1.0 & 32.0 \\
\hline
\end{tabular}

${ }^{1}$ Seif et al., 1973; Woodford et al., 1984; Holter and Urban, 1992; Silanikove et al., 1997; Osborne et al., 2002b, 2009; Kojima et al., 2005; Kume et al., 2010; Khelil-Arfa et al., 2014; Lamp et al., 2015.

${ }^{2} \mathrm{FWI}=$ drinking water intake, $\mathrm{DM}=$ dietary dry matter, $\mathrm{CP}$ and $\mathrm{NDF}=$ dietary $\mathrm{CP}$ and $\mathrm{NDF}$ contents, respectively, and TMP = daily mean ambient temperature. last explanatory variables, respectively; and $\nu(T)_{i j}$ and $\eta(S)_{j}=$ residual treatment and study-specific random deviations, respectively. Based on availability of data, 2 levels of explanatory variables were considered. Level 1 included DMI, milk yield, BW, DIM, and DM and dietary nutrient composition $(\mathrm{n}=188)$. Level 2 included Level 1 plus joint milliequivalent concentration of $\mathrm{Na}$ and $\mathrm{K}$ in diet $[\mathbf{N a K}, \mathrm{NaK}=$ dietary $\mathrm{Na}$ concentration $(\mathrm{mmol} / \mathrm{kg}$ of $\mathrm{DM})+$ dietary $\mathrm{K}$ concentration $(\mathrm{mmol} /$ $\mathrm{kg}$ of DM)], and TMP ( $\mathrm{n}=72)$. Mixed-effect models with and without DMI were developed in each level of the explanatory variables. Individual explanatory variables were first tested by regressing separately on FWI. Models including multiple explanatory variables were then formed with all possible combination of variables having notable effects $(P<0.10)$, when fitted individually. However, highly correlated variables $(|\mathrm{r}|>0.5)$ were not included together to minimize multicollinearity issues (Appuhamy et al., 2014a). For example, DMI and milk yield were regressed separately $(\mathrm{r}=0.67$, Table 3). Success of model fitting was primarily ranked using log-likelihood ratio test. When multiple models had similar likelihood values, the model associated with the least Bayesian information criteria was chosen as the best prediction model. All the meta-analyses were 
Table 3. Pearson correlation coefficients for the relationships among explanatory variables ${ }^{1}$ in the full data set $(\mathrm{n}=188)$

\begin{tabular}{|c|c|c|c|c|c|c|c|c|c|}
\hline Item & Milk & $\mathrm{DM}$ & $\mathrm{CP}$ & NDF & Ash & BW & DIM & $\mathrm{NaK}$ & TMP \\
\hline $\begin{array}{l}\text { DMI } \\
\text { Milk } \\
\text { DM } \\
\text { CP } \\
\text { NDF } \\
\text { Ash } \\
\text { BW } \\
\text { DIM } \\
\text { NaK }\end{array}$ & 0.67 & $\begin{array}{l}-0.24 \\
-0.35\end{array}$ & $\begin{array}{r}0.24 \\
0.44 \\
-0.37\end{array}$ & $\begin{array}{r}-0.10 \\
-0.08 \\
0.23 \\
0.06\end{array}$ & $\begin{array}{r}-0.01 \\
-0.07 \\
-0.02 \\
0.39 \\
0.44\end{array}$ & $\begin{array}{r}0.55 \\
0.46 \\
-0.22 \\
0.46 \\
0.39 \\
0.31\end{array}$ & $\begin{array}{r}-0.17 \\
-0.43 \\
-0.23 \\
-0.23 \\
-0.02 \\
0.03 \\
-0.15\end{array}$ & $\begin{array}{r}-0.32 \\
-0.47 \\
-0.36 \\
-0.27 \\
-0.17 \\
0.32 \\
-0.16 \\
0.38\end{array}$ & $\begin{array}{r}-0.48 \\
-0.37 \\
0.40 \\
0.13 \\
-0.19 \\
-0.25 \\
-0.13 \\
0.04 \\
-0.21\end{array}$ \\
\hline
\end{tabular}

${ }^{1}$ Milk = milk yield; $\mathrm{DM}=$ dietary dry matter; $\mathrm{CP}, \mathrm{NDF}$, ash, $\mathrm{Na}$, and $\mathrm{K}=$ dietary $\mathrm{CP}$, NDF, total ash, sodium, and potassium contents; $\mathrm{NaK}=$ dietary sodium and potassium milliequivalent content; and TMP = daily mean ambient temperature.

carried out using metafor package (Viechtbauer, 2010) in $\mathrm{R}$ (version 2.12.2, R Foundation for Statistical Computing, Vienna, Austria).

New models with and without DMI were evaluated with a separate data set including 261 FWI measurements $(\mathrm{kg} /$ cow per $\mathrm{d})$ made recently on lactating dairy cows in 3 independent studies. Two experiments conducted at the University of California-Davis provided 236 FWI measurements. In one experiment, 12 Holstein cows with an average milk production of $39.3 \pm 4.4 \mathrm{~kg} / \mathrm{d}$ and an average BW of $667 \pm 29 \mathrm{~kg}$ at the beginning of the study ( $157 \pm 31$ DIM) were randomly assigned to 2 dietary forage contents [ 37 vs. $53 \%$ of $\mathrm{DM}$ ] and 2 dietary CP concentrations (16.2 vs. $19.7 \%$ of DM) over 4 periods, each providing repeated measures of FWI (Niu et al., 2016). In the other experiment, 12 Holstein cows with an average BW of $696 \pm 47 \mathrm{~kg}$, and an average milk yield of $45.5 \pm 6.6 \mathrm{~kg} / \mathrm{d}$ at the beginning of the experiment $(130 \pm 20 \mathrm{DIM})$, were assigned to 2 doses of a fibrolytic enzyme (plus control) over 3 periods, where repeated measures of FWI were taken. The fibrolytic enzyme supplementation did not affect FWI (unpublished data). The Institutional Animal Care and Use Committee at the University of California-Davis approved all the animal procedures in the experiment. The rest of the FWI measurements were obtained from the experiments published in Fraley et al. (2015). The FWI measurements were related to considerably variable DMI (14.7 to 30.0 with a mean of $21.3 \mathrm{~kg} / \mathrm{d}$ ), milk yield (16.8 to 45.8 with a mean of $32.1 \mathrm{~kg} / \mathrm{d}$ ), DM\% (44.2 to 87.9 with a mean of $78.1 \%$ ), CP\% (14.4 to 18.8 with a mean of $16.6 \%$ of $\mathrm{DM}$ ), $\mathrm{NDF} \%$ (28.0 to 42.7 with a mean of $35.4 \%$ of DM), dietary Na content ( 0.16 to 0.40 with a mean of $0.24 \%$ of DM), dietary K content (1.03 to 3.35 with a mean of $1.34 \%$ of $\mathrm{DM}$ ), $\mathrm{NaK}$ (347 to 1013 with a mean of $450 \mathrm{mEq} / \mathrm{DM}$ of $\mathrm{kg}$ ), BW (518 to 807 with a mean of $664 \mathrm{~kg}$ ), DIM (121 to 262 with a mean of 193), and TMP (9.7 to 29.4 with a mean of $21.4^{\circ} \mathrm{C}$ ).
The overall agreement between model predictions and the data were determined by calculating the mean square prediction error (MSPE):

$$
\operatorname{MSPE}=\frac{1}{n} \cdot \sum_{i=1}^{n}\left(O_{i}-P_{i}\right)^{2},
$$

where $n=$ number of FWI observations, $O_{i}=i$ th observed value, $P_{i}=$ corresponding predicted value. As the square root of MSPE (RMSPE) carries the same unit of observed values, RMSPE was used to assess performance and was expressed as a percentage of average observed value (RMSPE\%). The RMSPE\% quantifies overall agreement between predicted and observed values but does not explain consistency of this agreement throughout the data range in question. Therefore, MSPE was decomposed into mean bias, slope bias, and bias due to random variability of data. Furthermore, agreement between predicted and observed values and presence of any bias were visually assessed with observed values versus predicted values plots and residual plots where prediction error (observed value predicted value) was regressed against predicted values centered on their mean. Prediction error regression line intersecting the zero error line (horizontal) in residual plots indicates the presence of slope bias. The intersection moving away from the intersection between the zero error line and zero centered-prediction value line (vertical) indicates the presence of mean bias. New and extant models for predicting FWI of lactating cows by Castle and Thomas (1975), Little and Shaw (1978), Murphy et al. (1983), Stockdale and King (1983), Dahlborn et al. (1998), Holter and Urban (1992), KhelilArfa et al. (2012), Appuhamy et al. (2014b), and Meyer et al. (2004) were evaluated.

Dry Cows. Two models were developed with and without DMI with the same meta-analytical approaches used for lactating cows. However, a quadratic 
relationship of TMP was tested by including squared TMP, which was centered on the mean TMP of $16.4^{\circ} \mathrm{C}$ $\left(\mathbf{T M P C}^{2}\right)$ in mixed-effect models. Centering on mean negated collinearity between TMP and $\mathrm{TMPC}^{2}(\mathrm{R}=$ 0.004, data not shown), when included in the same model. Due to paucity of data, the final dry cow models were evaluated only using the literature data themselves (internal evaluation) based on the same model evaluation criteria described above.

\section{RESULTS AND DISCUSSION}

The main goal of the study was to develop a set of empirical models to predict FWI by dairy cows over a wide range of feed intake, diet composition, milk production, and ambient temperatures, which have been previously shown to be significantly associated with FWI. The literature data assembled in this study included wide ranges of those variables that allow for the development of models, which are able to capture the true associations and have a sound extrapolation capacity. The random-effect meta-analytic approach used to construct the models also support extrapolation as it assumes the data to be a random sample of the total population. Eighty percent of the data used to develop the models was related to Holstein cows in North America, Europe, and Australia. However, only $10 \%$ of the data were from grazing cows. Therefore, the models could be more representative of cows in confinement dairy farms. Random-effect meta-analysis approaches also allow for estimating heterogeneity or variability of the response (e.g., FWI) across studies, and also examining what proportion of the heterogeneity could be explained with the factors of interest (e.g., DMI, diet composition, and ambient temperature). Given the significant link between FWI and DMI of dairy cows (Appuhamy et al., 2014b), the majority of extant models for predicting the FWI include DMI as an explanatory variable. On the other hand, accurately measuring DMI of individual cows in commercial dairy farms is challenging (Vallimont et al., 2010). Therefore, in this study 2 sets of models were developed for estimating FWI of lactating cows or dry cows with and without DMI as a predictor variable. Moreover, the models developed including and excluding the NaK and TMP effects allowed for examining significance of those effects on FWI, independent of feed intake, milk production, and dietary DM and other nutrient contents.

\section{Lactating Cow Models}

Models Without Mineral and Temperature Variables. The models developed using the full data set $(\mathrm{n}=188)$, that excluded NaK and TMP as candi- date explanatory variables are listed in Table 4 . The random-effect model analysis determined that the mean FWI of lactating cows was $78.4 \pm 2.6 \mathrm{~kg} / \mathrm{d}$, which was related to average DMI, milk yield, and DM\% of 18.3 $\mathrm{kg} / \mathrm{d}, 28.1 \mathrm{~kg} / \mathrm{d}$, and $53.3 \%$, respectively (Table 1 ). The analysis also revealed that total heterogeneity of FWI, which was the summation of variability of FWI within individual studies and variability of FWI among individual studies, was significant $\left(\tau^{2}=389 \pm 20, P<\right.$ 0.001). When the random-effect models were extended to mixed-effect meta-regression models, the final prediction model with DMI (Equation 1, Table 4) also included positive associations of dietary DM (DM\%), CP $(\mathrm{CP} \%)$, and ash $($ Ash\%) concentrations. This model was associated with $51 \%$ less heterogeneity $\left(\tau^{2}=191\right.$ vs. 389), indicating the variables explained more than half of total variability of FWI. When evaluated with the literature data used in model construction, the model had RMSPE\% of $18.1 \%$ (Table 4), with minor mean and slope bias (Table 4 and Figure 1). When DMI was not used as an explanatory variable, milk yield and BW predominantly influenced FWI (Equation 2, Table 4) because of strong positive relationships with DMI ( $\mathrm{r}=$ 0.67 and 0.55 , respectively, Table 3 ). The associations of milk yield and BW appeared to be independent of each other given the correlation between them was not strong in the data $(\mathrm{r}=0.46$, Table 3). As observed in the model with DMI, DM\%, and Ash\% continued to have positive relationships with FWI independent of milk yield and BW. The relationship of $\mathrm{CP} \%$ was not included in the model as it was confounded with milk yield and BW (Table 3). The model without DMI explained $46 \%$ of the heterogeneity $\left(\tau^{2}=210\right.$ vs. 389$)$, which was similar to the amount explained by the model using DMI (51\%), indicating the possibility for predicting FWI of lactating cows successfully in the absence of feed intake records.

Models With Mineral and Temperature Variables. The mean $(82.2 \pm 5.0$ vs. $78.4 \pm 2.6 \mathrm{~kg} / \mathrm{d})$ and heterogeneity $\left(\tau^{2}=425 \pm 21\right.$ vs. $\left.389 \pm 20\right)$ of FWI measurements $(\mathrm{n}=72)$ having $\mathrm{NaK}$ and TMP records were similar to those of full data set. The DMI, milk yield, DIM, and dietary nutrient composition ranges were similar between the 2 data sets. Moreover, the correlations of DMI and milk yield with FWI $(\mathrm{kg} / \mathrm{d})$ in the full and the reduced data sets were similar $[\mathrm{r}$ $=0.42$ vs. 0.36 , and $\mathrm{r}=0.26$ vs. 0.24 , respectively (data not shown)]. Correlations of dietary DM ( $\mathrm{r}=$ 0.36 vs. 0.35$), \mathrm{CP}(\mathrm{r}=0.11$ vs. 0.14$)$, and ash ( $\mathrm{r}=$ 0.40 vs. 0.42 ) concentrations with FWI (per kg of DMI) were also similar (data not shown). Therefore, the subset with NaK and TMP records was a representative sample of the full data set. When NaK and TMP were considered as candidate explanatory variables, the final 
APPUHAMY ET AL.

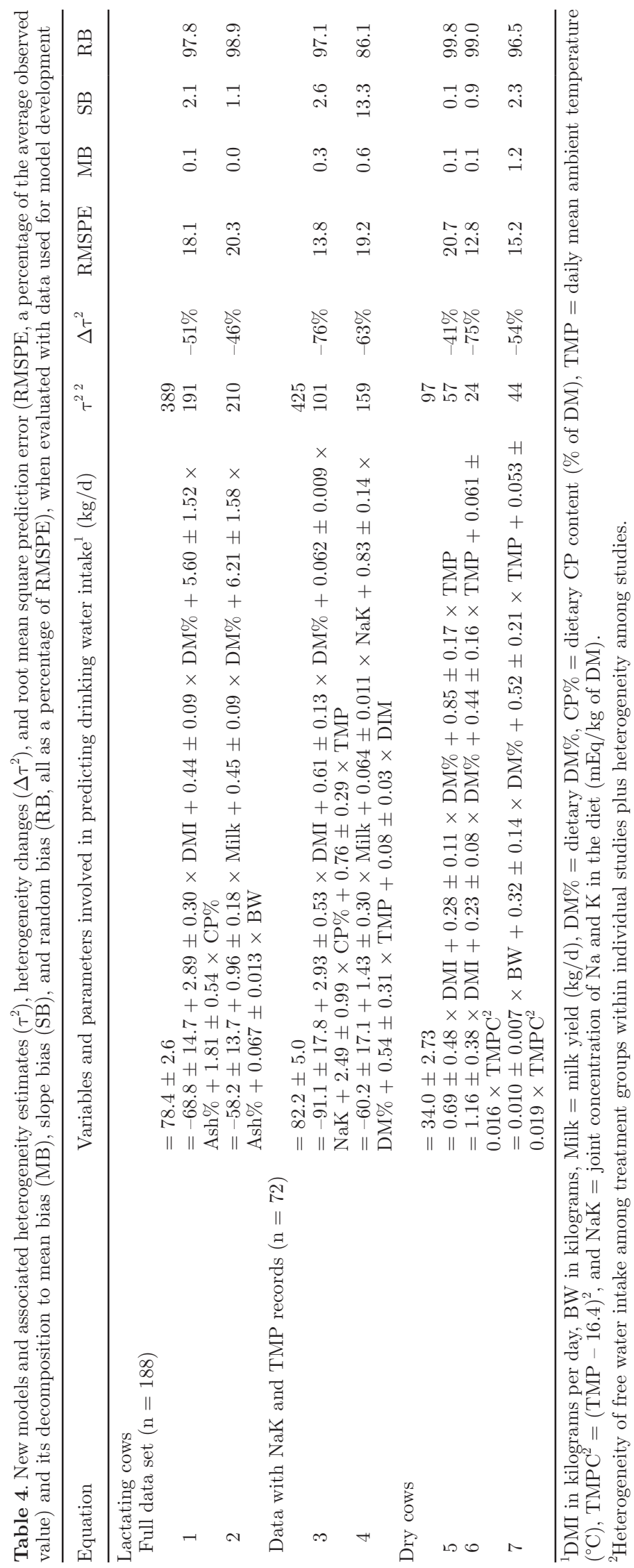


model with DMI included positive associations of NaK, TMP, DM\%, and CP\% with FWI (Equation 3, Table 4) and explained $76 \%$ of the heterogeneity. For each unit increase in DMI, FWI increased by $2.93 \pm 0.53 \mathrm{~kg} / \mathrm{d}$. This estimate is within the range of estimates $(2.38-3.22$ $\mathrm{kg} / \mathrm{d}$ ) reported by Murphy et al. (1983), Holter and Urban (1992), Khelil-Arfa et al. (2012), and Appuhamy et al. (2014b). Regardless of DMI, FWI increased by $0.61 \pm 0.13 \mathrm{~kg} / \mathrm{d}$ for a unit increase in DM\%. The effect size estimate of DM\% was also within the range of estimates $(0.27-0.83 \mathrm{~kg} / \mathrm{d})$ in extant models. Independent of DMI and DM\%, FWI increased by $0.062 \pm 0.009$ for each unit increase in NaK (Equation 3, Table 4). The positive association of $\mathrm{NaK}$ is consistent with several extant models (Murphy et al., 1983; Meyer et al., 2004) representing a positive effect of dietary $\mathrm{Na}$ intake on FWI, and dietary K intake mediating variable FWI in Fraley et al. (2015) and St Omer and Roberts (1967). Nonetheless, NaK, the aggregated dietary $\mathrm{Na}$ and $\mathrm{K}$ concentrations $(\mathrm{mEq} / \mathrm{kg}$ of $\mathrm{DM})$, made the model simpler and tended to have a better model fit than a model including dietary $\mathrm{Na}$ and $\mathrm{K}$ concentrations as 2 separate variables (data not shown).

Mean ambient temperature was positively and linearly associated with FWI within the range of 8.0 to $32.5^{\circ} \mathrm{C}$. The increase in water consumption is largely believed to be triggered by the increased need to support evaporative and respiratory heat losses (Pereira

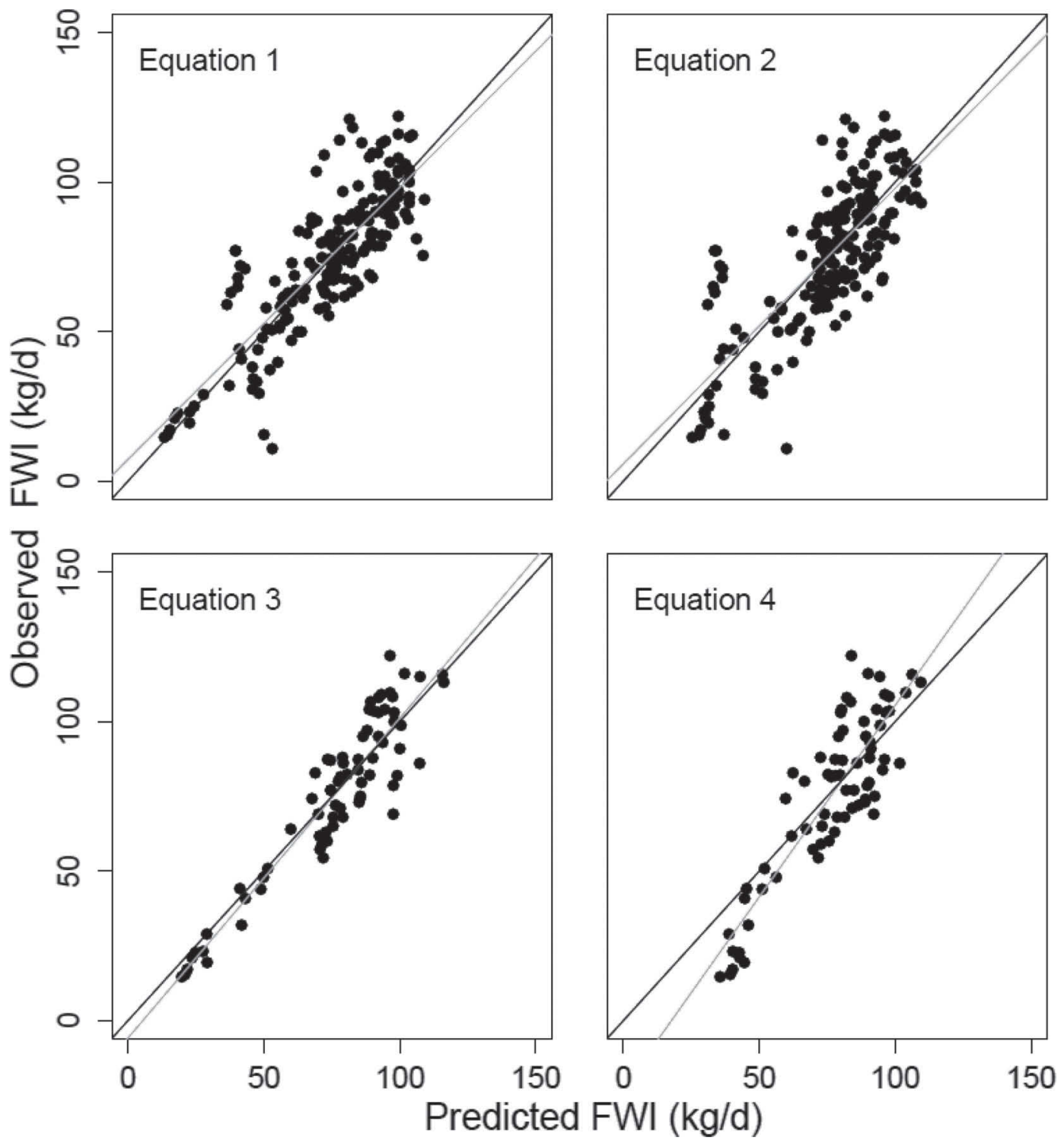

Figure 1. Observed versus predicted drinking water intake (FWI) of lactating dairy cows from new models, when evaluated with literature data used for model development. The black and gray lines represent, respectively, the unity line $(\mathrm{y}=\mathrm{x})$ and the scatter regression line. 
et al., 2014). We also tested a quadratic term of TMP but did not observe significant improvement in model fit (data not shown) with lactating cow data. For each unit $\left({ }^{\circ} \mathrm{C}\right)$ increase in TMP, FWI increased by $0.76 \pm$ $0.29 \mathrm{~kg} / \mathrm{d}$. In contrast, Meyer et al. (2004) estimated FWI to increase by a greater amount of $1.52 \mathrm{~kg} / \mathrm{d}$. The low effect size estimate in the new model (Equation 3, Table 4) may be partly due to confounding of TMP with DMI because DMI was negatively correlated with TMP in the data $(\mathrm{r}=-0.48$, Table 3$)$. Such a confounding is less likely in the model of Meyer et al. (2004) as DMI was not a direct covariate to the model although it was required to calculate dietary $\mathrm{Na}$ intake (Table 5). The $\mathrm{CP} \%$ had a positive association with FWI, independent of DMI and the other factors. For a unit increase in CP\%, FWI increased by $2.49 \pm 0.99 \mathrm{~kg} / \mathrm{d}$. Murphy et al. (1983) developed a model demonstrating FWI of dry cows to increase approximately $2.0 \mathrm{~kg} / \mathrm{d}$ for each unit increasing in $\mathrm{CP} \%$ within a $\mathrm{CP} \%$ range similar to the present data range (Table 1). The final model with DMI (Equation 3) was related to minor systematic bias $(<3.0 \%$ of total error, Table 4$)$, suggesting that that model could successfully predict FWI over wide ranges of the explanatory variables (i.e., DMI or milk yield). Consistently, the model still performed well (RMSPE $=16.3 \%$ with negligible mean bias, data not shown), when challenged only on FWI measurements related to high milk yields $(>35 \mathrm{~kg} / \mathrm{d})$.

Milk yield became a major driver of FWI in the absence of DMI in models owing to a strong positive relationship between DMI and milk yield (Equation 4, Table 4). Body weight was not included in the model without DMI as milk yield and BW had a stronger correlation than the correlation found in the full data set $[\mathrm{r}=0.75$ (data not shown) vs. 0.46 (Table 3)]. However, a positive association of DIM was included in the model, whereas DM\%, NaK, and TMP continue to be positively related to FWI (Equation 4 in Table 4). The model without DMI explained $63 \%$ of heterogeneity in FWI and was associated with a RMSPE\% of 19.2\%, when evaluated internally. Water intake predictions from the model without DMI had a slope bias indicating over prediction at low FWI, and under prediction at high FWI of lactating cows (Equation 4 in Figure 1).

Model Evaluation With Independent Data. Although the new models were developed with heterogeneous literature data presumably allowing for a sound extrapolating capacity, determination of real capacity requires them to be evaluated with independent data. Only the models developed for lactating cows were evaluated this way as an adequately large and variable independent data set could be achieved only for these cows. The independent FWI measurements were obtained recently from high producing (average milk yields of 39 to $46 \mathrm{~kg} / \mathrm{d}$ at 116 to 157 DIM) Holstein cows in the United States, and thus allowed for determining the relevance of new models to modern cows. The data covered reasonably wide ranges of DMI, milk yield, dietary DM, Na, and K contents, and TMP (CV $=16,18,16,24,28$, and 14\%, respectively). The $\mathrm{K}$ concentrations showed the greatest variability (1.03 to $3.35 \%$ of $\mathrm{DM}$ ) and included 4 observations (2.0\% of the data), which were greater than $3.0 \%$ of DM. Considering macrominerals are generally overfed (Castillo et al., 2013) and dietary $\mathrm{K}$ can increase up to $3.0 \%$ of DM in some US commercial dairy operations (Cela et al., 2014), those observations of high macromineral contents were included in the data set. The dietary $\mathrm{Na}$ concentrations were in line with the ranges of commercial farms (e.g., 0.25 and $0.58 \%$ of DM at the 10th and 90th percentiles; Castillo et al., 2013). The RMSPE and its components (mean, slope, and random bias) for new and extant models challenged on independent data are presented in Table 5. Consistent with the performances based on internal evaluation (Table 4), new models that used DMI as an explanatory variable had smaller prediction error compared with models without DMI. Moreover, new models including $\mathrm{NaK}$ and TMP predicted FWI more accurately than the models without those 2 factors (RMSPE\% $=14.4$ vs. $17.3 \%$, Table 5). Compared with all new and extant models, Equation 3 using DMI, DM\%, CP\%, NaK, and TMP as explanatory variables best predicted FWI of lactating cows (RMSPE\% = 14.4\%). The mean predicted FWI of the model was very close to the mean observed FWI as indicated by the small mean bias estimate $(0.1 \%$ of the total bias in Table 5). The model tended to overpredict at low FWI and under predict at high FWI (Figures 2 and 3), but this slope bias was small compared with the total prediction error $(4.1 \%)$, the majority $(95.8 \%$ in Table 5) of which was due the random variability of data. Overall, the presence of small mean and slope biases indicate the model parameters are fairly representative of the true relationships of DMI, DM\%, $\mathrm{CP} \%$, NaK, and TMP to FWI in the lactating cow population. Among extant models, those by Murphy et al. (1983) and Meyer et al. (2004) requiring DMI data performed well with RMSPE\% of $15.7 \%$. On average, the Murphy et al. (1983) model underpredicted FWI (Figure 3), whereas the Meyer et al. (2004) model overpredicted FWI (data not shown) to a similar extent as indicated by similar mean bias estimates (5.7 and $5.2 \%$, respectively, Table 5). Moreover, both extant models also overpredicted at low FWI and underpredicted at high FWI (Figures 2 and 3), but the slope biases were 2 to 3 times greater than that of the new model (8.3 and 
PREDICTING WATER INTAKE

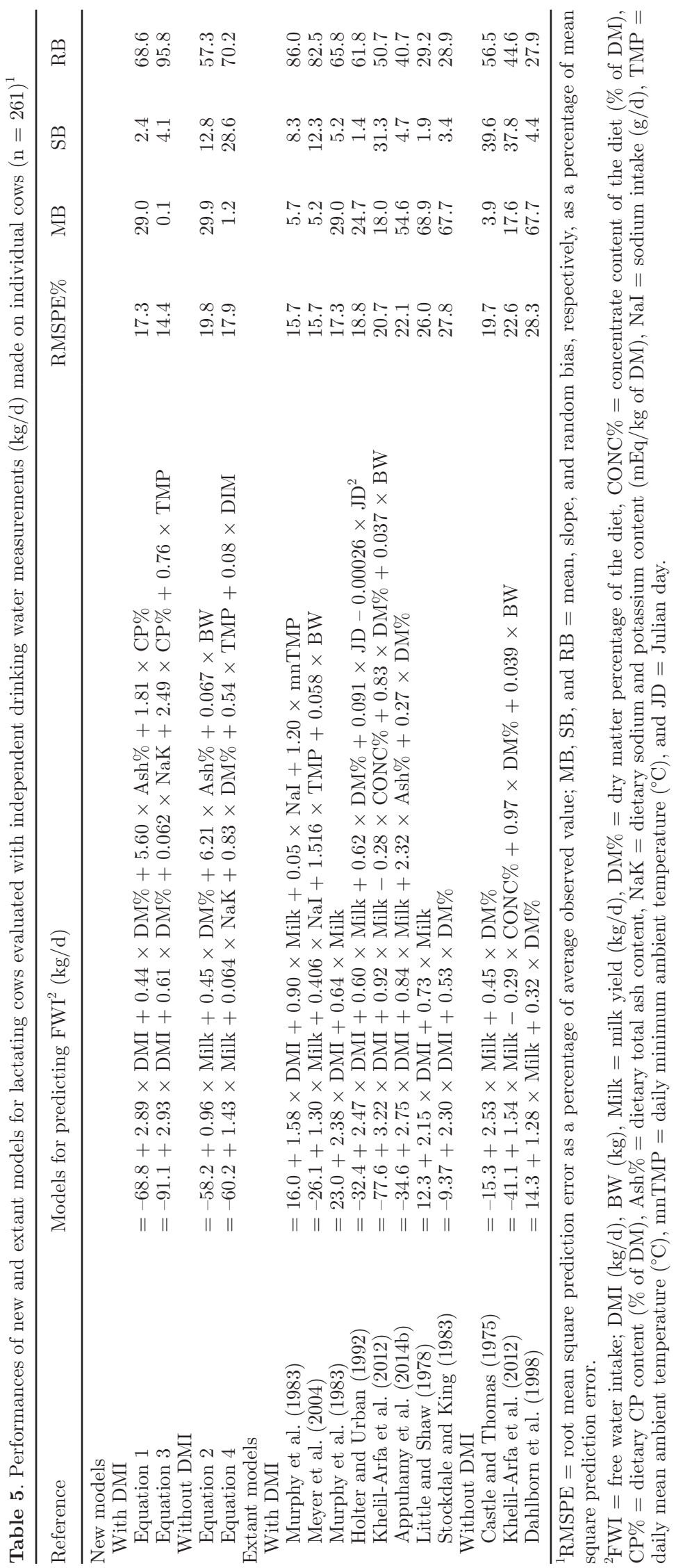


12.3 vs. $4.1 \%$, Table 5). Therefore, Equation 3 is recommended for predicting FWI of lactating dairy cows if DMI measurements of individual cows are available.

Although tie-stall or stanchion barns allow for measuring DMI of individual cows in some farms [e.g., in about $50 \%$ of US dairy farm operations (USDA, 2007)], accuracy of the measurements may be often challenged by wet feed refusals, an inability to individually weigh the feed delivered to each cow, and lack of feed dividers between cows (Vallimont et al., 2010). Therefore, a mathematical model not including DMI but based on reliable and routinely available information would benefit the majority of farms in determining FWI. Given the strong correlation of DMI with milk yield, reliable records of which are routinely available, a mathematical model including milk yield instead of DMI appears to be promising. Consistently, the new model (Equation 4) including milk yield, NaK, DM\%, and DIM best predicted FWI of lactating dairy cows. The extant model in Castle and Thomas (1975) including only milk yield and DM\% also performed well on independent data but had a larger RMSPE\% (19.7\%) than the RMSPE\% of the new model (17.9\%, Table 5). Predictions from the new model without DMI had small mean bias $(1.2 \%$ of total bias, Table 5$)$, although slope bias (28.6\% of total bias) was quite notable (Figure 3). Nonetheless, both mean and slope bias of the Castle and Thomas (1975) model were greater than those of the new model (Table $5)$. Therefore, Equation 4 is recommended for predicting FWI of lactating cows if the DMI measurements are not available.

Regardless of whether DMI is included or not, applicability of the new models can be limited in dairy farms using salt blocks [e.g., $15 \%$ of the farms in California (Castillo et al., 2013)] as determination of NaK is difficult. Alternatively, we re-evaluated the new models using $\mathrm{NaK}$ based on $\mathrm{Na}$ intake estimated according to NRC (2001) guidelines and found the models to perform well (RMSPE $=14.7$ and $19.7 \%$ for Equations 3 and 4 , respectively). This indicates a potential to predict FWI successfully, although determining the true mineral intake by animals is difficult. Another limitation of the model applicability would be unavailability of information on dietary macromineral content because some producers have financial limits for feed testing. Although, commercial mineral supplements will have a

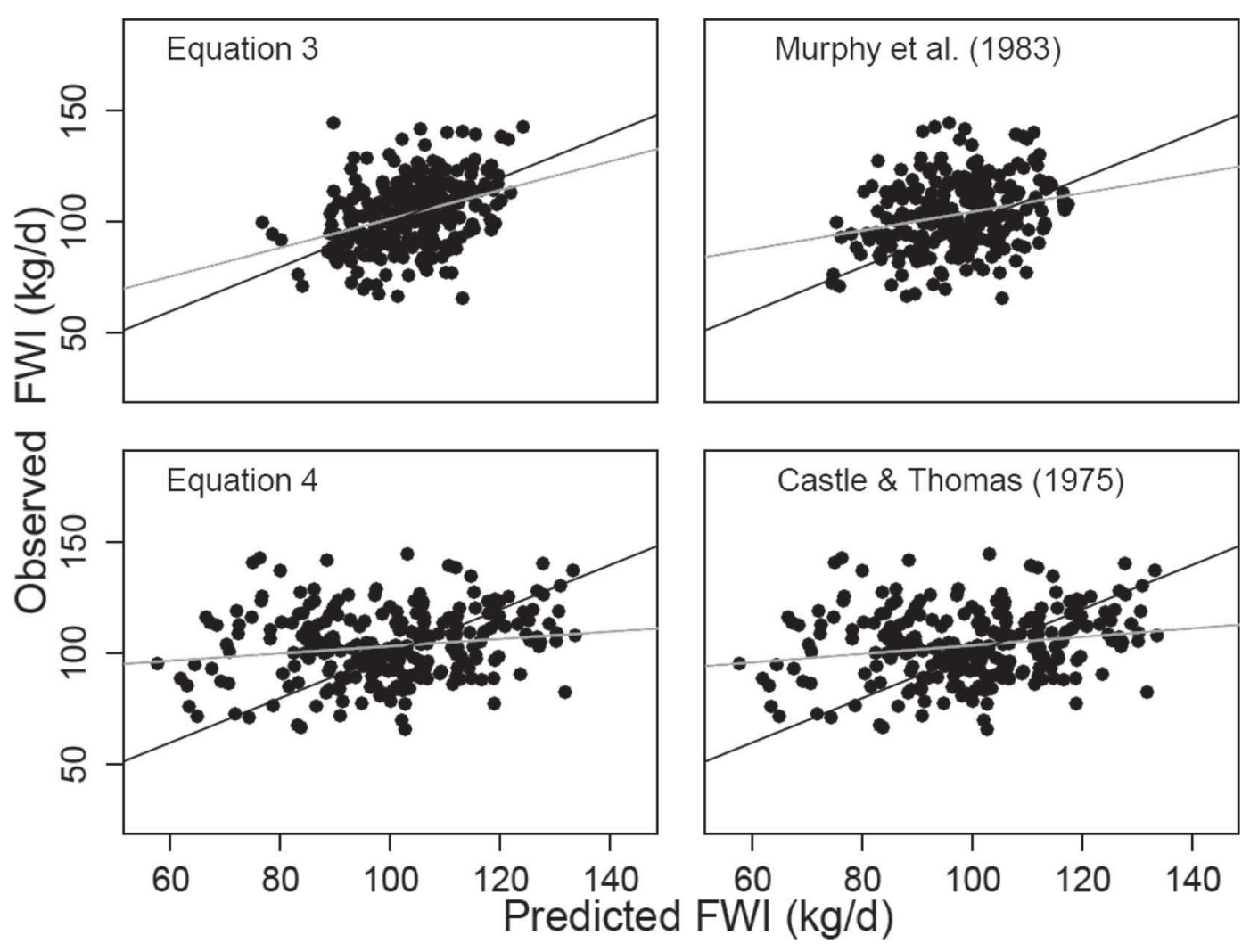

Figure 2. Observed versus predicted drinking water intake (FWI) of lactating cows from new models with (Equation 3) and without (Equation 4) DMI and extant models with [Murphy et al. (1983)] and without [Castle and Thomas (1975)] DMI, when evaluated with independent data. The black and gray lines represent, respectively, the unity line $(\mathrm{y}=\mathrm{x})$ and the scatter regression line. 


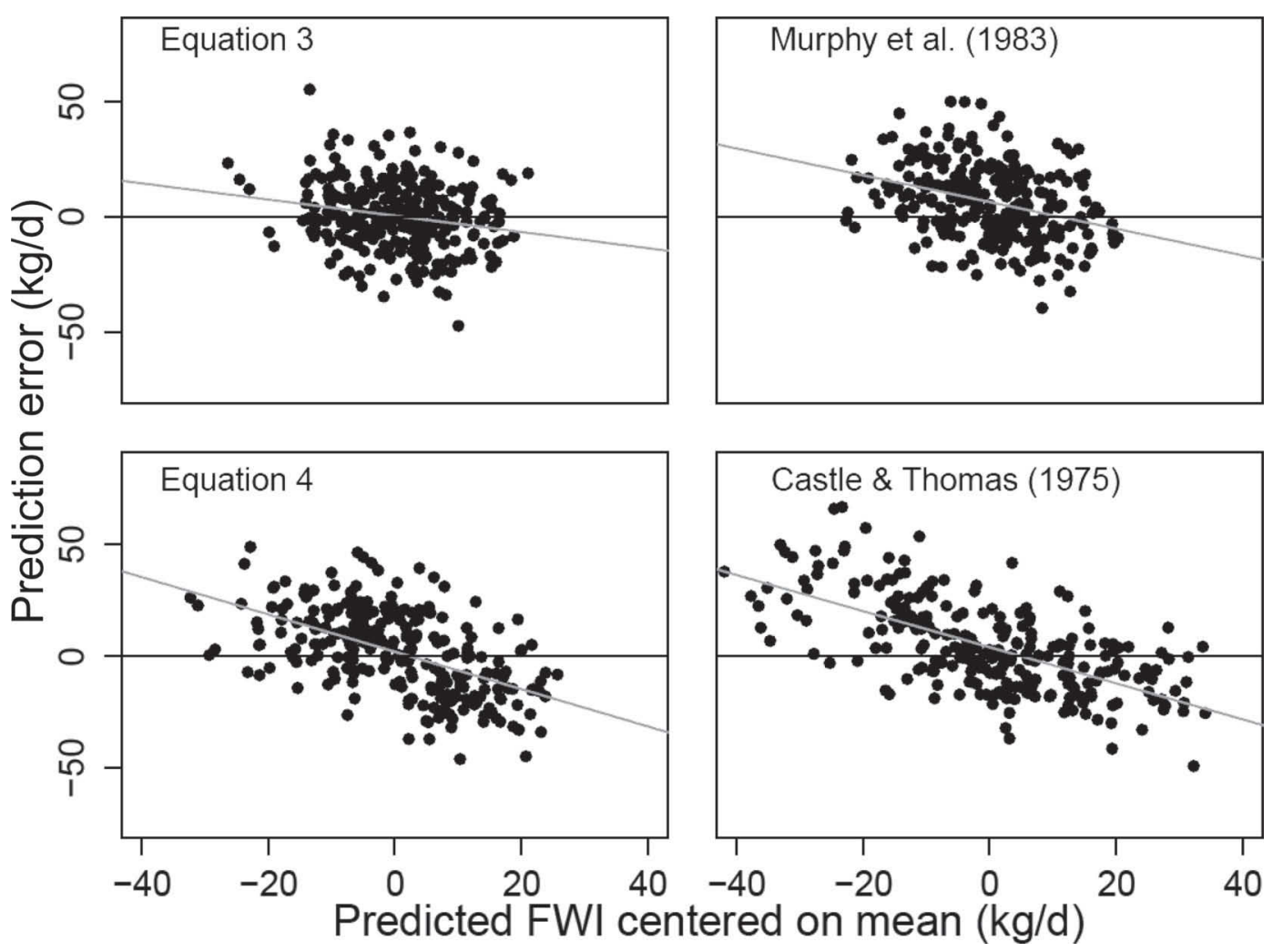

Figure 3. Prediction error (observed value - predicted value) versus predicted drinking water intake (FWI) of lactating cows from new models with (Equation 3) and without (Equation 4) DMI and extant models with [Murphy et al. (1983)] and without [Castle and Thomas (1975)] DMI, when evaluated with independent data. The black line represents the 0 error, whereas the gray line is the prediction error regression line.

guaranteed feed analysis and not require additional testing, forages are required to be tested for macrominerals as they are highly variable in mineral concentrations, particularly K (Norell and Chahine, 2014). Perhaps, as Norell and Chahine (2014) indicated, the table values of feed $\mathrm{Na}$ and $\mathrm{K}$ concentrations in NRC (2001) and a more recent analytical data set summarized by Beede (2005) might assist in determining FWI with reasonable accuracy.

\section{Dry Cow Models}

The average FWI of dry cows was estimated to be $34.0 \pm 2.73 \mathrm{~kg} / \mathrm{d}$ taking into account the heterogeneity $\left(\tau^{2}=98.2 \pm 38.3\right)$ of the FWI treatment means from literature (Table 4). This was less than half $(42 \%)$ of the FWI estimates for lactating cows. In addition to DMI, DM\% and TMP were positively associated with FWI of dry cows (Equations 5 and 6, Table 4). This is consistent with the observations of Holter and Urban (1992) who demonstrated significant associations of DMI and DM\% with FWI of dry cows under thermoneutral conditions. However, they also observed $\mathrm{CP} \%$ to be associated with FWI. Cattle have limited capac- ity to produce concentrated urine; therefore, they drink more water to dilute urinary urea, if excessive amounts of CP were fed (Holter and Urban, 1992; Appuhamy et al., 2014b). The maximum CP\% of diets in Holter and Urban (1992) was $23 \%$ of DM, suggesting that some cows entered a diuretic phase and consumed more water, allowing the link between $\mathrm{CP} \%$ and FWI to be prominent. Such a relationship was not observed in this study as the maximum $\mathrm{CP} \%$ of dry cows in our data was $16.6 \%$. The model that included a quadratic relationship of TMP (Equation 6) explained more variability of FWI than the model including a linear (Equation 5) relationship ( $\tau^{2}$ change $=-75$ vs. $-41 \%$, respectively). The link between FWI and TMP is consistent with the quadratic relationship of TMP (i.e., 10 to $36^{\circ} \mathrm{C}$ ) and respiratory cutaneous water loses from Holstein cows (Campos Maia et al., 2005, 2008). When evaluated with data used for model development, predicted and observed FWI were in a close agreement (Figure 2B) and had RMSPE of $12.8 \%$ indicating the model parameters would be fairly representative of true relationship of FWI to DMI, DM\%, and TMP. However, the model should be further evaluated using independent data when such data becomes available. Among extant mod- 

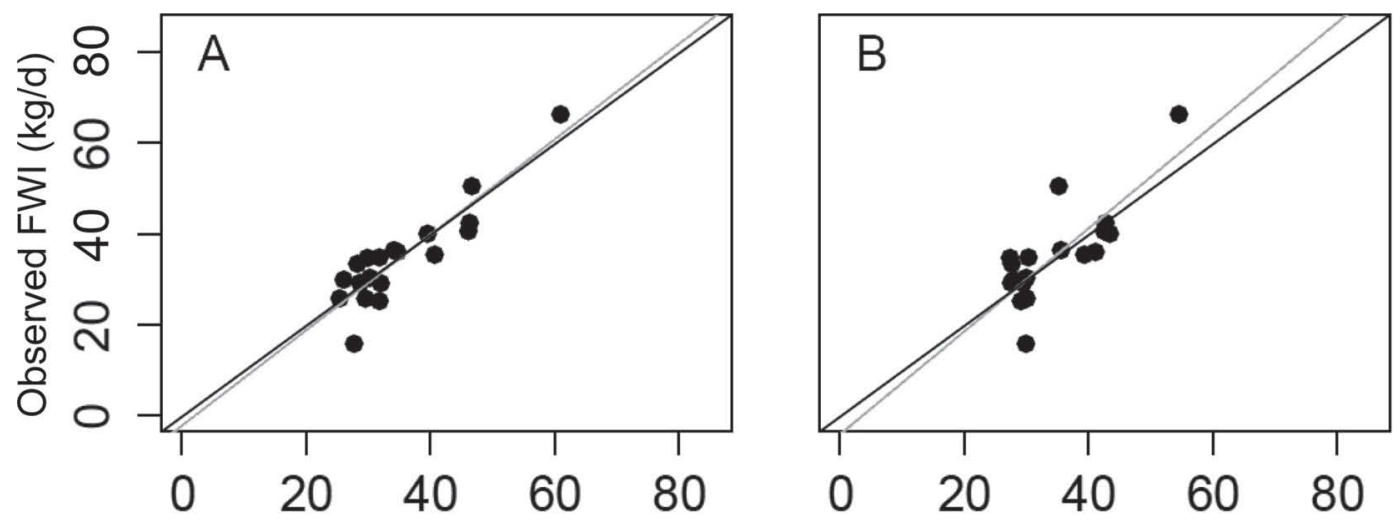

Predicted FWI $(\mathrm{kg} / \mathrm{d})$

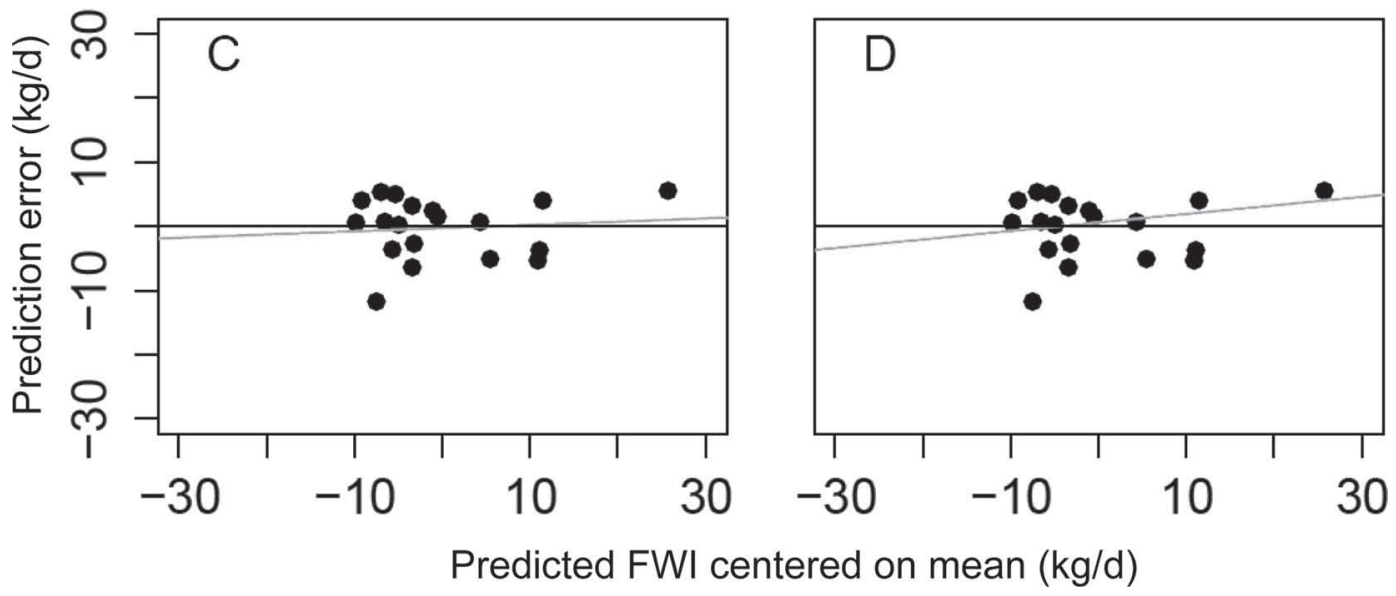

Figure 4. Observed versus predicted drinking water intake (FWI) from models with (A) and without (B) DMI, and prediction error versus predicted FWI centered on mean from models with (C) and without (D) DMI for dry cows. The black line represents the unity line (y = $\mathrm{x}$ ) in $\mathrm{A}$ and $\mathrm{B}$ and the 0 error in $\mathrm{C}$ and $\mathrm{D}$. The gray line is the scatter regression line.

els, only Holter and Urban (1992) offered a model to predict FWI of dry cows without requiring DMI data, which was solely based on CP\%. Equation 7 (Table 4) was developed without including DMI as a predictor variable. The model used $\mathrm{BW}, \mathrm{DM} \%$, and TMP variables and explained $54 \%$ of the heterogeneity of FWI (Table 4). Availability of DMI measurements appeared to be critical for predicting FWI of dry cows. However, the model without DMI had RMSPE\% of $15.2 \%$ (Table 4) without notable mean or slope bias (Figure 4), and therefore, may be useful in predicting FWI of dry cows.

\section{CONCLUSIONS}

When analyzed with data from 55 studies published in the literature, on average lactating cows consumed $78.4 \pm 2.6 \mathrm{~kg}$ of water each day. Heterogeneity of FWI across the studies was significant. Dry matter intake, dietary DM, CP, $\mathrm{Na}$ and $\mathrm{K}$ concentrations, and daily mean ambient temperature were positively and independently related to FWI of lactating dairy cows and explained $76 \%$ of the heterogeneity. A new empirical model including these variables predicted FWI more accurately compared with extant models with DMI (RMSPE\% $=14.4$ vs. $\geq 15.7 \%$ ). Therefore, the new model is recommended for predicting FWI of lactating dairy cows, if DMI records are available. In the absence of DMI records, milk yield, dietary DM, and $\mathrm{Na}$ and $\mathrm{K}$ contents, daily mean ambient temperature, and DIM were positively and independently related to FWI and explained $63 \%$ of the heterogeneity. A new empirical model including these variables predicted FWI more accurately compared with extant models that do not require DMI data $(\mathrm{RMSPE} \%=18.1$ vs. $\geq 19.7 \%$ ). Therefore, the new model is recommended for predicting FWI of the lactating dairy cows, if DMI records are not available. As observed with lactating cows, DMI, dietary DM content, and daily mean ambi- 
ent temperature were significantly related to FWI of dry cows and explained $75 \%$ of heterogeneity in FWI across 10 studies. In the absence of DMI records, BW, dietary DM content, and daily mean ambient temperature were significantly related to FWI and explained $54 \%$ of the heterogeneity. Two new empirical models developed using these variables with and without DMI variable performed well (RMSPE\% $=12.8$ and $15.2 \%$, respectively) and did not under- or overpredict FWI of dry cows over the data range (i.e., DMI varying from 6.7 to $21.8 \mathrm{~kg} / \mathrm{d}$ ). Overall, the present study offers a set of empirical models that can assist in estimating the drinking water intake by dairy cows in commercial dairy herds.

\section{ACKNOWLEDGMENTS}

Research was partially supported by the University of California-Davis Sesnon Endowed Chair Program and USDA National Institute of Food and Agriculture (Washington, DC) Multistate Research Project NC2040.

\section{REFERENCES}

Alvarez-Fuentes, G., J. A. D. R. N. Appuhamy, and E. Kebreab. 2016. Prediction of phosphorus output in manure and milk by lactating dairy cows. J. Dairy Sci. 99:771-782.

Anderson, M. 1987. Effects of free or restricted access to feeds and water, and social rank, on performance and behaviour of tied-up dairy cows. Swedish J. Agric. Res. 17:85-92.

Andersson, M. 1985. Effects of drinking water temperatures on water intake and milk yield of tied-up dairy cows. Livest. Prod. Sci. 12:329-338.

Andersson, M., J. Schaar, and H. Wiktorsson. 1984. Effects of drinking water flow rates and social rank on performance and drinking behaviour of tied-up dairy cows. Livest. Prod. Sci. 11:599-610.

Appuhamy, J. A. D. R. N., L. E. Moraes, C. Wagner-Riddle, D. P. Casper, J. France, and E. Kebreab. 2014a. Development of mathematical models to predict volume and nutrient composition of fresh manure from lactating Holstein cows. Anim. Prod. Sci. 54:1927-1938.

Appuhamy, J. A. D. R. N., C. Wagner-Riddle, D. P. Casper, J. France, and E. Kebreab. 2014b. Quantifying body water kinetics and fecal and urinary water output from lactating Holstein dairy cows. J. Dairy Sci. 97:6177-6195.

Bahman, A. M., J. A. Rooket, and J. H. Topps. 1993. The performance of dairy cows offered drinking water of low or high salinity in a hot arid climate. Anim. Sci. 57:23-28.

Beede, D. K. 2005. Formulation of rations with optimal cations and anions for lactation. Pages 93-112 in Proceedings of Tri State Dairy Nutrition Conference, Fort Wayne, IN. The Ohio State University, Columbus.

Beede, D. K. 2012. What will our ruminants drink? Anim. Front. 2:36-43.

Brown, W. E., and M. S. Allen. 2013. Effects of intrajugular glucose infusion on feed intake, milk yield, and metabolic responses of early postpartum cows fed diets varying in protein and starch concentration. J. Dairy Sci. 96:7132-7142.

Burgos, M. S., M. Senn, F. Sutter, M. Kreuzer, and W. Langhans. 2001. Effect of water restriction on feeding and metabolism in dairy cows. Am. J. Physiol. Regul. Integr. Comp. Physiol. 280:R418-R427.
Campos Maia, A., R. Gomes DaSilva, and C. Battiston Loureiro. 2005. Respiratory heat loss of Holstein cows in a tropical environment. Int. J. Biometeorol. 49:332-336.

Campos Maia, A., R. G. d. Silva, and C. M. B. Loureiro. 2008. Latent heat loss of Holstein cows in a tropical environment: A prediction model. Rev. Bras. Zootec. 37:1837-1843.

Cardot, V., Y. Le Roux, and S. Jurjanz. 2008. Drinking behavior of lactating dairy cows and prediction of their water intake. J. Dairy Sci. 91:2257-2264.

Castillo, A. R., N. R. St-Pierre, N. Silva del Rio, and W. P. Weiss. 2013. Mineral concentrations in diets, water, and milk and their value in estimating on-farm excretion of manure minerals in lactating dairy cows. J. Dairy Sci. 96:3388-3398.

Castle, M. E., and T. P. Thomas. 1975. The water intake of British Friesian cows on rations containing various forages. Anim. Sci. 20:181-189.

Castle, M. E., and J. N. Watson. 1973. The intake of drinking water by grazing dairy cows. The effect of water availability. Grass Forage Sci. 28:203-208.

Cela, S., Q. M. Ketterings, K. Czymmek, M. Soberon, and C. Rasmussen. 2014. Characterization of nitrogen, phosphorus, and potassium mass balances of dairy farms in New York state. J. Dairy Sci. 97:7614-7632.

Chaiyabutr, N., S. Chanpongsang, and S. Suadsong. 2008. Effects of evaporative cooling on the regulation of body water and milk production in crossbred Holstein cattle in a tropical environment. Int. J. Biometeorol. 52:575-585.

Chaiyabutr, N., S. Thammacharoen, S. Komolvanich, and S. Chanpongsang. 2007. Effects of long term exogenous bovine somatotropin on nutrients uptake by the mammary gland of crossbred Holstein cattle in the tropics. Asian-australas. J. Anim. Sci. 20:1407-1416

Cottee, G., I. Kyriazakis, T. M. Widowski, M. I. Lindinger, J. P. Cant, T. F. Duffield, V. R. Osborne, and B. W. McBride. 2004. The effects of subacute ruminal acidosis on sodium bicarbonatesupplemented water intake for lactating dairy cows. J. Dairy Sci. 87:2248-2253.

Dado, R. G., and M. S. Allen. 1993. Continuous computer acquisition of feed and water intakes, chewing, reticular motility, and ruminal pH of cattle. J. Dairy Sci. 76:1589-1600.

Dado, R. G., and M. S. Allen. 1994. Variation in and relationships among feeding, chewing, and drinking variables for lactating dairy cows. J. Dairy Sci. 77:132-144

Dado, R. G., and M. S. Allen. 1995. Intake limitations, feeding behavior, and rumen function of cows challenged with rumen fill from dietary fiber or inert bulk. J. Dairy Sci. 78:118-133.

Dado, R. G., and M. S. Allen. 1996. Enhanced intake and production of cows offered ensiled alfalfa with higher neutral detergent fiber digestibility. J. Dairy Sci. 79:418-428.

Dahlborn, K., M. Akerlind, and G. Gustafson. 1998. Water intake by dairy cows selected for high or low milk-fat percentage when fed two forages to concentrate ratios with hay or silage. Swed. J. Agric. Res. 28:167-176.

Dewhurst, R. J., N. W. Offer, and C. Thomas. 1998. Factors affecting water intakes of lactating dairy cows offered grass silages differing in fermentation and intake characteristics. Anim. Sci. 66:543-550.

Eriksson, T., and B. O. Rustas. 2014. Effects on milk urea concentration, urine output, and drinking water intake from incremental doses of potassium bicarbonate fed to mid-lactation dairy cows. J. Dairy Sci. 97:4471-4484.

Fraley, S. E., M. B. Hall, and T. D. Nennich. 2015. Effect of variable water intake as mediated by dietary potassium carbonate supplementation on rumen dynamics in lactating dairy cows. J. Dairy Sci. 98:3247-3256.

Genther, O. N., and D. K. Beede. 2013. Preference and drinking behavior of lactating dairy cows offered water with different concentrations, valences, and sources of iron. J. Dairy Sci. 96:1164-1176.

Gorewit, R. C., D. J. Aneshansley, D. C. Ludington, R. A. Pellerin, and X. Zhao. 1989. AC voltages on water bowls: Effects on lactating Holsteins. J. Dairy Sci. 72:2184-2192. 
Harvatine, K. J., and M. S. Allen. 2006. Effects of fatty acid supplements on feed intake, and feeding and chewing behavior of lactating dairy cows. J. Dairy Sci. 89:1104-1112.

Hoekstra, A. Y. 2012. The hidden water resource use behind meat and dairy. Anim. Front. 2:3-8.

Holter, J. B., M. J. Slotnick, H. H. Hayes, C. K. Bozak, W. E. Urban Jr., and M. L. McGilliard. 1990. Effect of prepartum dietary energy on condition score, postpartum energy, nitrogen partitions, and lactation production responses. J. Dairy Sci. 73:3502-3511.

Holter, J. B., J. A. Byrne, and C. G. Schwab. 1982. Crude protein for high milk production. J. Dairy Sci. 65:1175-1188.

Holter, J. B., H. H. Hayes, W. E. Urban Jr., and A. H. Duthie. 1992. Energy balance and lactation response in Holstein cows supplemented with cottonseed with or without calcium soap. J. Dairy Sci. 75:1480-1494.

Holter, J. B., and W. E. Urban Jr.. 1992. Water partitioning and intake prediction in dry and lactating Holstein cows. J. Dairy Sci. $75: 1472-1479$

Janicki, F. J., J. B. Holter, and H. H. Hayes. 1985. Varying protein content and nitrogen solubility for pluriparous, lactating Holstein cows: Digestive performance during early lactation. J. Dairy Sci. 68:1995-2008.

Khelil-Arfa, H., A. Boudon, G. Maxin, and P. Faverdin. 2012. Prediction of water intake and excretion flows in Holstein dairy cows under thermoneutral conditions. Animal 6:1662-1676.

Khelil-Arfa, H., P. Faverdin, and A. Boudon. 2014. Effect of ambient temperature and sodium bicarbonate supplementation on water and electrolyte balances in dry and lactating Holstein cows. J. Dairy Sci. 97:2305-2318.

Kojima, H., S. Kume, K. Nonaka, T. Oshita, T. Kozakai, and H. Hirooka. 2005. Effects of feeding and animal performance on nitrogen, phosphorus and potassium excretion by Holstein cows. Anim. Sci. J. 76:139-145.

Konstantopoulos, S. 2011. Fixed effects and variance components estimation in three-level meta-analysis. Res. Synth. Methods 2:61-76.

Kramer, E., E. Stamer, J. Spilke, G. Thaller, and J. Krieter. 2009. Analysis of water intake and dry matter intake using different lactation curve models. J. Dairy Sci. 92:4072-4081.

Kume, S., K. Nonaka, T. Oshita, and T. Kozakai. 2010. Evaluation of drinking water intake, feed water intake and total water intake in dry and lactating cows fed silages. Livest. Sci. 128:46-51.

Kume, S., K. Nonaka, T. Oshita, T. Kozakai, and H. Hirooka. 2008. Effects of urinary excretion of nitrogen, potassium and sodium on urine volume in dairy cows. Livest. Sci. 115:28-33.

Lamp, O., M. Derno, W. Otten, M. Mielenz, G. Nürnberg, and B. Kuhla. 2015. Metabolic heat stress adaption in transition cows: Differences in macronutrient oxidation between late-gestating and early-lactating German Holstein dairy cows. PLoS ONE 10:e0125264.

Lassiter, J. W., and H. M. J. Edwards. 1982. Animal Nutrition. Reston Publishing Company, Reston, VA.

Little, W., B. F. Sansom, R. Manston, and W. M. Allen. 1976. Effects of restricting the water intake of dairy cows upon their milk yield, body weight and blood composition. Anim. Sci. 22:329-339.

Little, W., and S. R. Shaw. 1978. A note on the individuality of the intake of drinking water by dairy cows. Anim. Sci. 26:225-227.

Longuski, R. A., Y. Ying, and M. S. Allen. 2009. Yeast culture supplementation prevented milk fat depression by a short-term dietary challenge with fermentable starch. J. Dairy Sci. 92:160-167.

McBeth, L. R., N. R. St-Pierre, D. E. Shoemaker, and W. P. Weiss. 2013. Effects of transient changes in silage dry matter concentration on lactating dairy cows. J. Dairy Sci. 96:3924-3935.

Meyer, U., M. Everinghoff, D. Gädeken, and G. Flachowsky. 2004 Investigations on the water intake of lactating dairy cows. Livest. Prod. Sci. 90:117-121.

Mooney, C. S., and M. S. Allen. 1997. Physical effectiveness of the neutral detergent fiber of whole linted cottonseed relative to that of alfalfa silage at two lengths of cut. J. Dairy Sci. 80:2052-2061.

Muller, C. J. C., J. A. Botha, and W. W. Smith. 1994. Effect of shade on various parameters of Friesian cows in a Mediterranean climate in South Africa. 1. Feed and water intake, milk production and milk composition. S. Afr. J. Anim. Sci. 24:49-55.

Murphy, M. R., C. L. Davis, and G. C. McCoy. 1983. Factors affecting water consumption by Holstein cows in early lactation. J. Dairy Sci. 66:35-38.

Niu, M., J. A. D. R. N. Appuhamy, A. B. Leytem, R. S. Dungan, and E. Kebreab. 2016. Effect of dietary crude protein and forage contents on enteric methane emissions and nitrogen excretion from dairy cows simultaneously. Anim. Prod. Sci. 56:312-321.

Nocek, J. E., and D. G. Braund. 1985. Effect of feeding frequency on diurnal dry matter and water consumption, liquid dilution rate, and milk yield in first lactation. J. Dairy Sci. 68:2238-2247.

Norell, R., and M. Chahine. 2014. Impact of macro mineral nutrition ( $\mathrm{Na}, \mathrm{K}, \mathrm{Mg}, \mathrm{Ca}$ ) of dairy cows on nutrient excretion. Idaho Nutrient Management Conference Proceedings.

NRC. 2001. Nutrient Requirements of Dairy Cattle. 7th rev. ed. National Academy Press, Washington, DC.

Osborne, V. R., R. R. Hacker, and B. W. McBride. 2002a. Effects of heated drinking water on the production responses of lactating Holstein and Jersey cows. Can. J. Anim. Sci. 82:267-273.

Osborne, V. R., K. E. Leslie, and B. W. McBride. 2002b. Effect of supplementing glucose in drinking water on the energy and nitrogen status of the transition dairy cow. Can. J. Anim. Sci. 82:427-433.

Osborne, V. R., N. E. Odongo, J. P. Cant, K. C. Swanson, and B. W. McBride. 2009. Effects of supplementing glycerol and soybean oil in drinking water on feed and water intake, energy balance, and production performance of periparturient dairy cows. J. Dairy Sci. 92:698-707.

Pereira, A. M., E. L. Titto, P. Infante, C. G. Titto, A. M. Geraldo, A. Alves, T. M. Leme, F. Baccari Jr., and J. A. Almeida. 2014. Evaporative heat loss in Bos taurus: Do different cattle breeds cope with heat stress in the same way? J. Therm. Biol. 45:87-95.

Reith, S., M. Pries, C. Verhülsdonk, H. Brandt, and S. Hoy. 2014 Influence of estrus on dry matter intake, water intake and BW of dairy cows. Animal 8:748-753.

Richards, J. I. 1985. Effect of high daytime temperatures on the intake and utilisation of water in lactating Friesian cows. Trop. Anim. Health Prod. 17:209-217.

Schulte, P., J. Morrison, S. Woodward, J. Anderson, T. Calandro, S. Howell, and L. Stonefield. 2014. Bridging concern and action: Are US companies prepared for looming water challenges? Report by the Pacific Institute and VOX Global.

Seif, S. M., H. D. Johnson, and L. Hahn. 1973. Environmental heat and partial water restriction effects on body fluid spaces, water loss, body temperature, and metabolism of Holstein cows. J. Dairy Sci. $56: 581-586$

Shalit, U., E. Maltz, N. Silanikove, and A. Berman. 1991. Water, sodium, potassium, and chlorine metabolism of dairy cows at the onset of lactation in hot weather. J. Dairy Sci. 74:1874-1883.

Shapasand, M., A. R. Alizadeh, M. Yousefi, and J. Amini. 2010. Performance and physiological responses of dairy cattle to water total dissolved solids (TDS) under heat stress. J. Appl. Anim. Res. $38: 165-168$.

Silanikove, N., E. Maltz, A. Halevi, and D. Shinder. 1997. Metabolism of water, sodium, potassium, and chlorine by high yielding dairy cows at the onset of lactation. J. Dairy Sci. 80:949-956.

Spek, J. W., A. Bannink, G. Gort, W. H. Hendriks, and J. Dijkstra. 2012. Effect of sodium chloride intake on urine volume, urinary urea excretion, and milk urea concentration in lactating dairy cattle. J. Dairy Sci. 95:7288-7298.

St Omer, V. V. E., and W. K. Roberts. 1967. Some effects of dietary potassium upon digestibility, serum electrolytes and utilization of potassium, sodium, nitrogen and water in heifers. Can. J. Anim. Sci. 47:39-46.

Steiger Burgos, M., M. Senn, F. Sutter, M. Kreuzer, and W. Langhans. 2001. Effect of water restriction on feeding and metabolism in dairy cows. Am. J. Physiol. Regul. Integr. Comp. Physiol. 280:R418-R427.

Stockdale, C. R., and K. R. King. 1983. A note on some of the factors that affect the water consumption of lactating dairy cows at pasture. Anim. Sci. 36:303-306. 
Stocks, S. E., and M. S. Allen. 2012. Hypophagic effects of propionate increase with elevated hepatic acetyl coenzyme a concentration for cows in the early postpartum period. J. Dairy Sci. 95:3259-3268.

Taylor, C. C., and M. S. Allen. 2005. Corn grain endosperm type and brown midrib 3 corn silage: Feeding behavior and milk yield of lactating cows. J. Dairy Sci. 88:1425-1433.

Thomas, L. C., T. C. Wright, A. Formusiak, J. P. Cant, and V. R. Osborne. 2007. Use of flavored drinking water in calves and lactating dairy cattle. J. Dairy Sci. 90:3831-3837.

USDA. 2007. Part I: Reference of dairy cattle health and management practices in the United States, 2007. N480.1007. USDA-APHISVS, CEAH, Fort Collins, CO.

Vallimont, J. E., C. D. Dechow, J. M. Daubert, M. W. Dekleva, J. W. Blum, C. M. Barlieb, W. Liu, G. A. Varga, A. J. Heinrichs, and C. R. Baumrucker. 2010. Genetic parameters of feed intake, production, body weight, body condition score, and selected type traits of Holstein cows in commercial tie-stall barns. J. Dairy Sci. 93:4892-4901.

Viechtbauer, W. 2010. Conducting meta-analysis in $\mathrm{r}$ with the metafor package. J. Stat. Softw. 36:1-48.

Voelker, J. A., and M. S. Allen. 2003. Pelleted beet pulp substituted for high-moisture corn: 1. Effects on feed intake, chewing behavior, and milk production of lactating dairy cows. J. Dairy Sci. 86:3542-3552.

Woodford, S. T., M. R. Murphy, and C. L. Davis. 1984. Water dynamics of dairy cattle as affected by initiation of lactation and feed intake. J. Dairy Sci. 67:2336-2343. 